\title{
Erratum to: An abelisaurid humerus from the Upper Cretaceous of India
}

\author{
Ariel H. Méndez • Fernando E. Novas • \\ Sankar Chatterjee
}

Published online: 2 July 2010

(C) Springer-Verlag 2010

\section{Erratum to: Paläontol Z}

\section{DOI 10.1007/s12542-010-0055-z}

Owing to an unfortunate oversight, the legend to Fig. 1 does not indicate that the figure was modified from Wilson et al. (2003):

Wilson, J.A., P.C. Sereno, S. Srivastava, D.K. Bhatt, A. Khosla, and A. Sahni. 2003. A new abelisaurid (Dinosauria, Theropoda) from the Lameta Formation (Cretaceous, Maastrichtian) of India. Contributions from the Museum of Paleontology, University of Michigan 31: $1-42$.

The authors apologize for this omission.

The online version of the original article can be found under doi:10.1007/s12542-010-0055-z.

\footnotetext{
A. H. Méndez $(\bowtie) \cdot$ F. E. Novas Conicet, Laboratorio de Anatomía Comparada y Evolución de los Vertebrados, Museo Argentino de Ciencias Naturales "Bernardino Rivadavia", Av. Ángel Gallardo 470,

1405, Buenos Aires, Argentina

e-mail: arielhmendez@yahoo.com.ar

S. Chatterjee

Department of Geosciences, Museum of Texas Tech University, Box 43191, Lubbock, TX 79409-3191, USA
} 